\title{
Proteomic Analysis Identifies an NADPH Oxidase 1 (Nox1)-Mediated Role for Actin-Related Protein 2/3 Complex Subunit 2 (ARPC2) in Promoting Smooth Muscle Cell Migration
}

\author{
Imad Al Ghouleh ${ }^{1,2}$, Andrés Rodríguez ${ }^{1,2, \dagger}$, Patrick J. Pagano ${ }^{1,2, *}$ and Gábor Csányi ${ }^{1,2, *}$ \\ 1 Vascular Medicine Institute, $12^{\text {th }}$ Floor BST, 200 Lothrop Street, University of Pittsburgh, \\ PA 15261, USA; E-Mails: ima6@pitt.edu (I.A.G.); anigrodriguez@gmail.com (A.R.) \\ 2 Department of Pharmacology \& Chemical Biology, $13^{\text {th }}$ Floor BST, 200 Lothrop Street, \\ University of Pittsburgh, PA 15261, USA \\ $\dagger$ Current address: Instituto do Coração, Hospital Das Clinicas Faculdade De Medicina Da USP, \\ Av. Eneas Carvalho Aguiar, 44. Vascular Biology Laboratory $-9^{\text {th }}$ Floor, Anexo 2 Sao Paulo, Brazil. \\ * Authors to whom correspondence should be addressed; E-Mails: pagano@pitt.edu (P.J.P.); \\ gac22@pitt.edu (G.C.); Tel.: +1-412-383-6505 (P.J.P.); +1-412-624-3640 (G.C.); \\ Fax: +1-412-648-5980 (P.J.P.); +1-412-648-3046 (G.C.).
}

Received: 8 August 2013; in revised form: 28 August 2013 / Accepted: 16 September 2013 / Published: 11 October 2013

\begin{abstract}
A variety of vascular pathologies, including hypertension, restenosis and atherosclerosis, are characterized by vascular smooth muscle cell (VSMC) hypertrophy and migration. NADPH oxidase 1 (Nox1) plays a pivotal role in these phenotypes via distinct downstream signaling. However, the mediators differentiating these distinct phenotypes and their precise role in vascular disease are still not clear. The present study was designed to identify novel targets of VSMC Nox1 signaling using 2D Differential In-Gel Electrophoresis and Mass Spectrometry (2D-DIGE/MS). VSMC treatment with scrambled (Scrmb) or Nox1 siRNA and incubation with the oxidant hydrogen peroxide $\left(\mathrm{H}_{2} \mathrm{O}_{2}\right.$; $50 \mu \mathrm{M}, 3 \mathrm{~h}$ ) followed by 2D-DIGE/MS on cell lysates identified 10 target proteins. Among these proteins, actin-related protein $2 / 3$ complex subunit 2 (ARPC2) with no previous link to Nox isozymes, $\mathrm{H}_{2} \mathrm{O}_{2}$, or other reactive oxygen species (ROS), was identified and postulated to play an intermediary role in VSMC migration. Western blot confirmed that Nox1 mediates $\mathrm{H}_{2} \mathrm{O}_{2}$-induced ARPC2 expression in VSMC. Treatment with a p38 MAPK inhibitor (SB203580) resulted in reduced ARPC2 expression in $\mathrm{H}_{2} \mathrm{O}_{2}$-treated VSMC.
\end{abstract}


Additionally, wound-healing "scratch" assay confirmed that $\mathrm{H}_{2} \mathrm{O}_{2}$ stimulates VSMC migration via Nox1. Importantly, gene silencing of ARPC2 suppressed $\mathrm{H}_{2} \mathrm{O}_{2}$-stimulated VSMC migration. These results demonstrate for the first time that Nox1-mediated VSMC migration involves ARPC2 as a downstream signaling target.

Keywords: vascular smooth muscle cell; migration; NADPH oxidase; oxidative stress; ARPC2

\section{Introduction}

Vessel wall remodeling plays a key role in the development of vascular disorders, including systemic hypertension and atherosclerosis [1,2]. Proliferation and migration of vascular smooth muscle cells (VSMC) as well as extracellular matrix rearrangement are important early mechanisms in the pathogenesis of vascular disease [3]. However, the molecular mechanisms differentiating these events are not well defined.

Reactive oxygen species (ROS), namely superoxide anion $\left(\mathrm{O}_{2}{ }^{-}\right)$and hydrogen peroxide $\left(\mathrm{H}_{2} \mathrm{O}_{2}\right)$, mediate signal transduction pathways contributing to the pathophysiological responses of VSMC, including proliferation, migration, and hypertrophy [4,5]. A major source of ROS in VSMC during vascular remodeling is the NADPH oxidase (Nox) family of enzymes [6]. Rodent conduit artery VSMC express Nox1 and Nox4 [7]. Nox1 primarily generates $\mathrm{O}_{2}{ }^{--}$, while Nox4 appears to constitutively produce $\mathrm{H}_{2} \mathrm{O}_{2}[8,9]$. In addition, these Nox isoforms serve distinct functions within cells, purportedly a consequence of their distinct intracellular compartmentalization, unique mechanism of regulation and activation, and the ROS they produce. Our laboratory has recently demonstrated that pathophysiologically-relevant concentrations of $\mathrm{H}_{2} \mathrm{O}_{2}$ stimulate Nox1-derived $\mathrm{O}_{2}{ }^{--}$generation in rat aortic VSMC, leading to activation of apoptosis signal-regulating kinase 1 (Ask1). These data delineated a previously unknown molecular cascade by which feed-forward ROS signaling in the vascular wall is propagated [10]. Irrespective of the stimulant, previous data demonstrate that VSMC Nox1 activation is at the core of a network of vascular ROS signaling [10,11]. The means by which Nox1 directs phenotypic changes in the vascular wall is an ongoing area of intense interest in our laboratory.

Previous studies have established that Nox-derived ROS play an important role in VSMC migration [11]. Indeed, conduit artery VSMC overexpressing $\mathrm{p} 22^{\text {phox }}$, the membrane-bound subunit associated with the Nox catalytic core, demonstrate increased migratory ability compared to wild type controls [12]. In order to identify novel targets of Nox1 activation in VSMC, the current study employed 2D Differential In-Gel Electrophoresis and mass spectrometry (2D DIGE/MS). Proteomic analysis using 2D DIGE/MS revealed a Nox1-mediated upregulation of VSMC actin-related protein 2/3 complex subunit 2 (ARPC2). The data demonstrated that VSMC migration via Nox1 involves ARPC2, shedding light on a new signaling pathway in vascular biology. 


\section{Results and Discussion}

\subsection{D-Gel Proteomic Analysis Identifies Novel Proteins Downstream of Nox1 Activation in VSMC}

To identify proteins upregulated or downregulated by feed-forward ROS-induced Nox1 activation, rat aortic VSMC transfected with scrambled (Scrmb) or Nox1 short interfering RNA (siRNA) were incubated with $\mathrm{H}_{2} \mathrm{O}_{2}(50 \mu \mathrm{M}, 3 \mathrm{~h})$ and compared to each other and to vehicle-treated non-transfected VSMC (control). Utilization of fluorescent dyes that complex with all proteins in a sample allows for use of 2D gel technology to compare multiple samples simultaneously. Taking advantage of this technique, each of the three samples were labeled with one particular CyDye (Cy3 for control, Cy2 for Scrmb siRNA $+\mathrm{H}_{2} \mathrm{O}_{2}$, and $\mathrm{Cy} 5$ for Nox1 siRNA $+\mathrm{H}_{2} \mathrm{O}_{2}$ ) and loaded simultaneously onto a 2D gel. For the analysis, two conditions were compared at a time using the DeCyder 2D Differential Analysis Software (version 6.5) as detailed in Table 1. Ninety six gel spots were selected for further analysis based on spot intensity changes and in-gel resolution (Figure 1).

Table 1. Comparisons among treatment groups conducted by the DeCyder software.

\begin{tabular}{ccc}
\hline Comparison & \multicolumn{2}{c}{ Treatment conditions } \\
\hline 1 & Control & Scrmb siRNA $+\mathrm{H}_{2} \mathrm{O}_{2}$ \\
2 & Control & Nox1 siRNA $+\mathrm{H}_{2} \mathrm{O}_{2}$ \\
3 & Scrmb siRNA $+\mathrm{H}_{2} \mathrm{O}_{2}$ & Nox1 siRNA $+\mathrm{H}_{2} \mathrm{O}_{2}$ \\
\hline
\end{tabular}

Figure 1. Representative 2D gel images. Vascular smooth muscle cells (VSMC) incubated with vehicle (control) or transfected with Scrmb or Nox1 siRNA and treated with $\mathrm{H}_{2} \mathrm{O}_{2}$ $(50 \mu \mathrm{M}, 3 \mathrm{~h})$ were lysed and fluorescently labeled with $\mathrm{Cy} 3, \mathrm{Cy} 2$, or Cy5, respectively and run on a $2 \mathrm{D}$ gel $(n=1)$. Images show the comparisons of two fluorescent channels at a time (assigned green and red pseudocolors) as presented in Table 1. Vertical scale indicates the molecular weight ladder; lower horizontal scale denotes $\mathrm{pH}$ gradient. The 96 gel spots selected by DeCyder are annotated by white numbers.
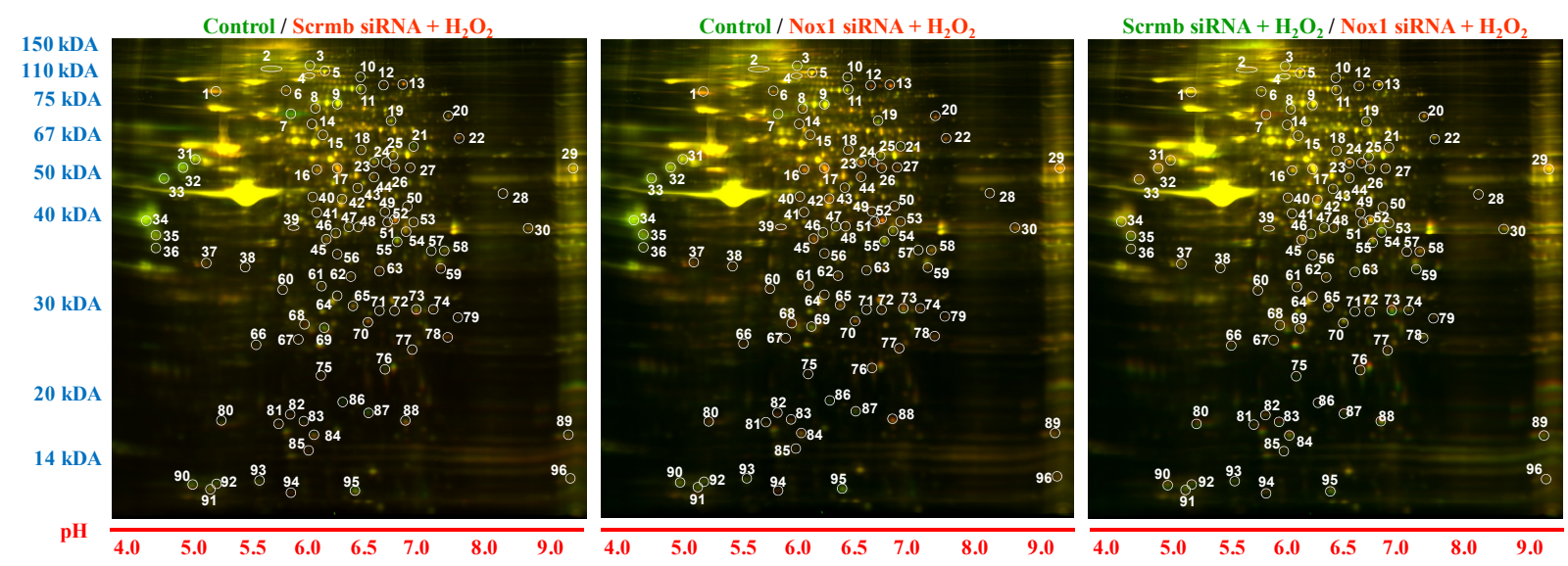

For each of the identified gel spots, fluorescence intensity from the two wavelengths as well as spot areas were quantified using the DeCyder software. Next, 3D intensity plots were generated and compared between treatment conditions. Figure 2 shows a representative 3D image for spot "63", which corresponds to ARPC2 (see Table 2). 
Figure 2. 3D view of representative spot intensity. Spot 63 is shown with the DeCyder calculation of fluorescence intensity for each treatment group per comparison. The selected spot is marked by a yellow circle on the $2 \mathrm{D}$ gel $(n=1)$.
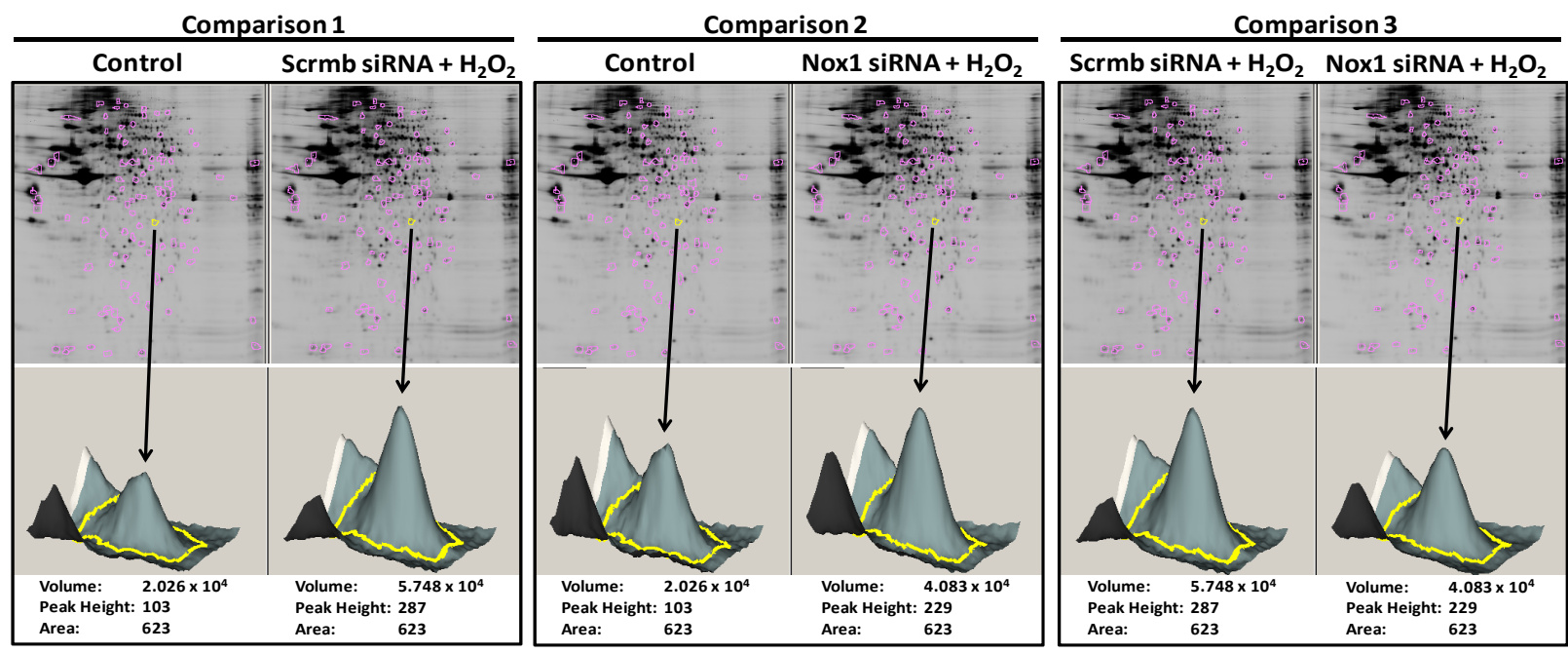

Table 2. List of VSMC proteins up or downregulated by $\mathrm{H}_{2} \mathrm{O}_{2}$ treatment in a Nox1-dependent manner.

\begin{tabular}{|c|c|c|c|c|c|c|c|}
\hline $\begin{array}{c}\text { Spot } \\
\text { number }\end{array}$ & Protein name & $\begin{array}{l}\text { Up/Down- } \\
\text { regulation }\end{array}$ & $\begin{array}{l}\text { Accession } \\
\text { No. }\end{array}$ & $\begin{array}{l}\text { Protein } \\
\text { Score }\end{array}$ & $\begin{array}{c}\text { Molecular } \\
\text { weight } \\
\text { (Da) } \\
\end{array}$ & $\begin{array}{c}\text { Protein Score } \\
\text { C. I.\%/Total } \\
\text { Ion C. I.\% } \\
\end{array}$ & Major function \\
\hline 2 & $\begin{array}{l}\text { Fibronectin 1, } \\
\text { isoform CRA_d }\end{array}$ & $\downarrow$ & gi|149015981 & 411 & 262,586 & $100 / 100$ & $\begin{array}{l}\text { Cell adhesion and } \\
\text { differentiation }\end{array}$ \\
\hline 4 & $\begin{array}{c}\text { Heterogeneous } \\
\text { nuclear } \\
\text { ribonucleoprotein } \mathrm{U}\end{array}$ & $\uparrow$ & gi|148747541 & 601 & 87,678 & $100 / 100$ & $\begin{array}{c}\text { Regulation of mRNA } \\
\text { metabolism and } \\
\text { transport }\end{array}$ \\
\hline 7 & Fibronectin 3 & $\downarrow$ & gi|204158 & 111 & 74,876 & $100 / 100$ & $\begin{array}{c}\text { Wound healing, cell } \\
\text { adhesion and } \\
\text { differentation }\end{array}$ \\
\hline 32 & $\begin{array}{c}\text { Vimentin, isoform } \\
\text { CRA_b }\end{array}$ & $\downarrow$ & gi|149021114 & 1,250 & 53,668 & $100 / 100$ & $\begin{array}{c}\text { Type III intermediate } \\
\text { filament, maintains } \\
\text { cellular integrity }\end{array}$ \\
\hline 33 & Vimentin & $\downarrow$ & gi|14389299 & 1350 & 53,700 & $100 / 100$ & $\begin{array}{c}\text { Type III intermediate } \\
\text { filament, maintains } \\
\text { cellular integrity }\end{array}$ \\
\hline 57 & $\begin{array}{l}\text { Insulin-like growth } \\
\text { factor (IGF)- } \\
\text { binding protein } 2 \\
\text { precursor }\end{array}$ & $\downarrow$ & gi||148747421 & 584 & 32,833 & $100 / 100$ & $\begin{array}{c}\text { Regulates } \\
\text { bioavailability of IGF }\end{array}$ \\
\hline 59 & $\begin{array}{c}36 \text { kda voltage } \\
\text { dependent anion } \\
\text { channel }\end{array}$ & $\uparrow$ & gi|299036 & 355 & 31,700 & $100 / 100$ & $\begin{array}{l}\text { Voltage-dependent } \\
\text { anion channel protein }\end{array}$ \\
\hline
\end{tabular}


Table 2. Cont.

\begin{tabular}{cccccccc}
\hline $\begin{array}{c}\text { Spot } \\
\text { number }\end{array}$ & Protein name & $\begin{array}{c}\text { Up/Down- } \\
\text { regulation }\end{array}$ & $\begin{array}{c}\text { Accession } \\
\text { No. }\end{array}$ & $\begin{array}{c}\text { Protein } \\
\text { Score }\end{array}$ & $\begin{array}{c}\text { Molecular } \\
\text { weight } \\
\text { (Da) }\end{array}$ & $\begin{array}{c}\text { Protein Score } \\
\text { C. I.\%/Total } \\
\text { Ion C. I.\% }\end{array}$ & Major function \\
\hline 63 & ARPC2 & $\uparrow$ & gi|205686193 & 823 & 34,369 & $100 / 100$ & $\begin{array}{c}\text { Regulation of actin } \\
\text { cytoskeleton }\end{array}$ \\
\hline 86 & Cofilin-1 & $\downarrow$ & gi|8393101 & 148 & 18,520 & $100 / 100$ & $\begin{array}{c}\text { Regulation of actin } \\
\text { cytoskeleton } \\
\text { dynamics }\end{array}$ \\
\hline 87 & Destrin & $\downarrow$ & gi|62665569 & 241 & 18,507 & $100 / 100$ & $\begin{array}{c}\text { Actin- } \\
\text { depolymerizing } \\
\text { protein }\end{array}$ \\
\hline
\end{tabular}

VSMC proteins either up or downregulated in a Nox1-dependent mechanism were identified if they satisfied the following criteria:

(a) Comparison 1: "Scrmb siRNA $+\mathrm{H}_{2} \mathrm{O}_{2}$ "/“control" $\geq 1$ 1.3-fold or $\leq 0.7$-fold

(b) Comparisons $1 \&$ 2: ("Scrmb siRNA $+\mathrm{H}_{2} \mathrm{O}_{2}$ "/"control") - ("Nox1 siRNA $+\mathrm{H}_{2} \mathrm{O}_{2}$ "/"control") $\geq 0.3$-fold or $\leq-0.3$-fold

(c) Comparison 3: "Scrmb siRNA $+\mathrm{H}_{2} \mathrm{O}_{2}$ "/"Nox1 siRNA $+\mathrm{H}_{2} \mathrm{O}_{2}$ " $\geq 0.2$ fold. Control connotes vehicle treatment in untransfected VSMC.

The criterion for "c" was selected to reflect a 0.2 -fold change in the positive or negative direction (rather than 0.3-fold) to limit the stringency and increase the number of potential candidates of interest.

Using these criteria, 10 spots were selected for protein identification. Of these, 3 spots exhibited an increase in intensity following treatment relative to control, corresponding to protein upregulation. The remaining 7 spots showed a decrease in intensity, which corresponds to protein downregulation in response to $\mathrm{H}_{2} \mathrm{O}_{2}$ (Table 2). The selected spots were analyzed by MS followed by a proteomic in silico determination of protein identities within each spot (Table 2).

From the identified proteins, ARPC2 displayed no previous link to Nox isozymes or ROS. Accordingly, we selected this protein as a potential new signaling mediator modulated by Nox1. ARPC2 is $34 \mathrm{kDa}$ protein that together with ARP2, ARP3, ARPC1B, ARPC3, ARPC4, and ARPC5 form the ARP2/3 complex [13]. The ARP2/3 complex is involved in regulation of actin cytoskeleton, functioning as a nucleation site for new actin filament formation and therefore cytoskeletal branching [14]. Previous data reported a link between ARP2/3 complex and cell migration [15-17]. Nevertheless, the role of ARPC2 in potential modulation of cell migration, particularly under oxidative conditions remained unexplored.

\subsection{Upregulation of ARPC2 Protein Expression in VSMCs via Nox1}

To verify the reliability of proteomic analysis, ARPC2 protein expression was analyzed by Western blot. VSMC were transfected with Nox1 or Scrmb siRNA and treated with vehicle or $50 \mu \mathrm{M} \mathrm{H}_{2} \mathrm{O}_{2}$ for $3 \mathrm{~h}$. Nox1 protein expression was previously determined to be suppressed by $\sim 70 \%$ using Nox 1 siRNA without affecting Nox4 expression [10] (Nox2 and Nox5 are not expressed in rat aortic VSMC [7,10]). 
As shown in Figure 3, treatment of VSMC with $\mathrm{H}_{2} \mathrm{O}_{2}$ significantly increased ARPC2 expression. Gene silencing of Nox1 using siRNA significantly decreased ARPC2 expression in $\mathrm{H}_{2} \mathrm{O}_{2}$-treated VSMC.

Figure 3. Upregulation of ARPC2 protein expression in VSMCs via Nox1. Nox1 and Scrmb siRNA-treated VSMC were incubated with vehicle or $50 \mu \mathrm{M} \mathrm{H}_{2} \mathrm{O}_{2}$ for $3 \mathrm{~h}$. VSMC lysates were subjected to Western blot and probed with a polyclonal antibody against ARPC2 (Aviva Systems Biology) and $\beta$-actin (Santa Cruz Biotechnology). (A) Representative Western blot; (B) Bar graphs representing averaged optical density data expressed as a ratio of ARPC2 to $\beta$-actin $(n=6)$. Data represent the mean \pm SEM. ${ }^{*} p<0.05 v s$. Scrmb siRNA + vehicle treatment; ${ }^{\#} p<0.05$ vs. Scrmb siRNA $+\mathrm{H}_{2} \mathrm{O}_{2}$ treatment.

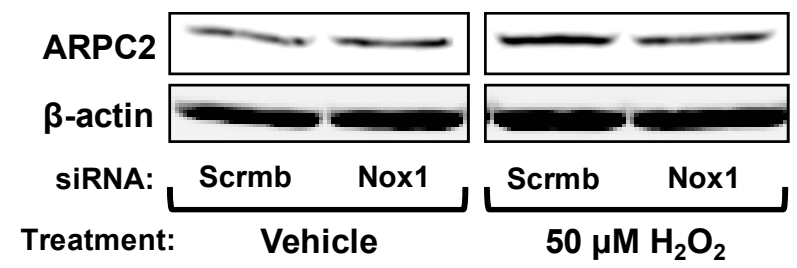

(A)

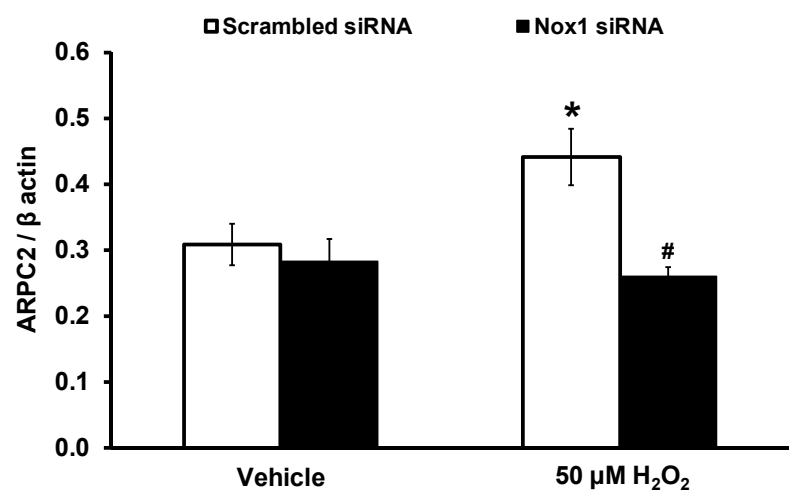

(B)

\section{3. $\mathrm{H}_{2} \mathrm{O}_{2}$ Stimulates VSMC Migration via Nox1}

ROS mediate important cellular processes including, but not limited to, migration and proliferation [4,5]. To confirm the role of Nox1 in VSMC migration in our experimental setting, Nox1 and Scrmb siRNA-transfected VSMC were wounded by scratching the cellular monolayer $(0 \mathrm{~h})$ and incubated for $24 \mathrm{~h}$ with vehicle or $\mathrm{H}_{2} \mathrm{O}_{2}(50 \mu \mathrm{M})$. As shown in Figure $4, \mathrm{H}_{2} \mathrm{O}_{2}$ treatment significantly increased migration of Scrmb siRNA-transfected VSMC compared to vehicle treatment. In addition, gene silencing of Nox 1 completely abolished the effect of $\mathrm{H}_{2} \mathrm{O}_{2}$ on VSMC migration, demonstrating for the first time that $\mathrm{H}_{2} \mathrm{O}_{2}$ stimulates VSMC migration via Nox1. Taken together with our previous findings $[10,18]$, these data further support the notion of ROS as positive feed-forward regulators of Nox. 
Figure 4. $\mathrm{H}_{2} \mathrm{O}_{2}$ stimulates VSMC migration via Nox1. VSMC were transfected with Scrmb or Nox1 siRNA and treated with vehicle or $\mathrm{H}_{2} \mathrm{O}_{2}(50 \mu \mathrm{M})$. Cell migration was determined by wounding of VSMC monolayers. Wound area was monitored at 0 and $24 \mathrm{~h}$. (A) Representative images taken at 0 and $24 \mathrm{~h}$ after wounding (original magnification, $\times 10$ ). Dashed lines denote the approximate edge of the wound at these time points; (B) Quantitative assessment of the data $(n=3)$. Data represent the mean \pm SEM. $* p<0.05$ vs. Scrmb siRNA + vehicle treatment; ${ }^{\#} p<0.05$ vs. Scrmb siRNA $+\mathrm{H}_{2} \mathrm{O}_{2}$ treatment.

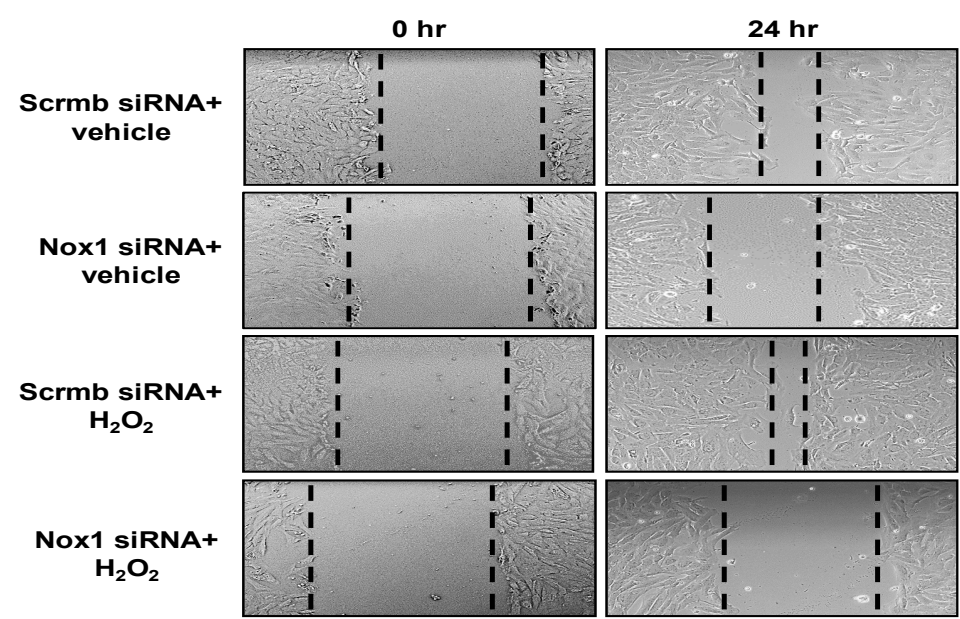

(A)

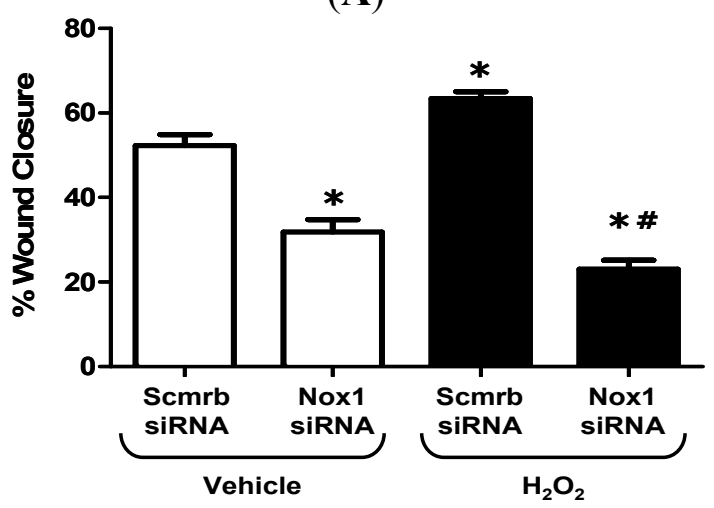

(B)

To investigate whether increased cellular proliferation in response to $\mathrm{H}_{2} \mathrm{O}_{2}$ treatment contributes to wound closure, VSMC proliferation was investigated using the carboxyfluorescein diacetate succinimidyl ester (CFSE) proliferation assay. Cells were treated with vehicle or $\mathrm{H}_{2} \mathrm{O}_{2}(50 \mu \mathrm{M})$ and proliferation was determined by the extent of reduction in CFSE fluorescence as a consequence of dilution into daughter cells at $24 \mathrm{~h}$. Figure 5 demonstrates that $\mathrm{H}_{2} \mathrm{O}_{2}$ treatment did not increase VSMC proliferation following $24 \mathrm{~h}$ of treatment (proliferating cells: $3.7 \pm 0.9$ and $4.0 \% \pm 0.6 \%$ of total for vehicle and $\mathrm{H}_{2} \mathrm{O}_{2}$ treatments, respectively). 
Figure 5. $\mathrm{H}_{2} \mathrm{O}_{2}(50 \mu \mathrm{M})$ tyreatment for $24 \mathrm{~h}$ does not stimulate VSMC proliferation. serum-starved (0.1\% FBS, $24 \mathrm{~h})$ VSMC were pretreated with CFSE $(1.25 \mu \mathrm{M}, 15 \mathrm{~min})$ and incubated with vehicle or $50 \mu \mathrm{M} \mathrm{H}_{2} \mathrm{O}_{2}$. Twenty four hours later CFSE fluorescence was evaluated using a BD LSRFortessa ${ }^{\mathrm{TM}}$ cell analyzer and flow data were analyzed using FlowJo (version 10). (A) Histograms showing CFSE fluorescence intensities in unstained controls (grey fill) and CFSE-stained VSMC treated with vehicle (green tracing) or $\mathrm{H}_{2} \mathrm{O}_{2}$ (red tracing). VSMC incubated for $48 \mathrm{~h}$ in the presence of complete growth media $(10 \%$ fetal bovine serum; FBS) were used as positive controls (black tracing); (B) Quantitative assessment of VSMC proliferation $(n=3)$. Data represent the mean $\pm \mathrm{SEM}$.

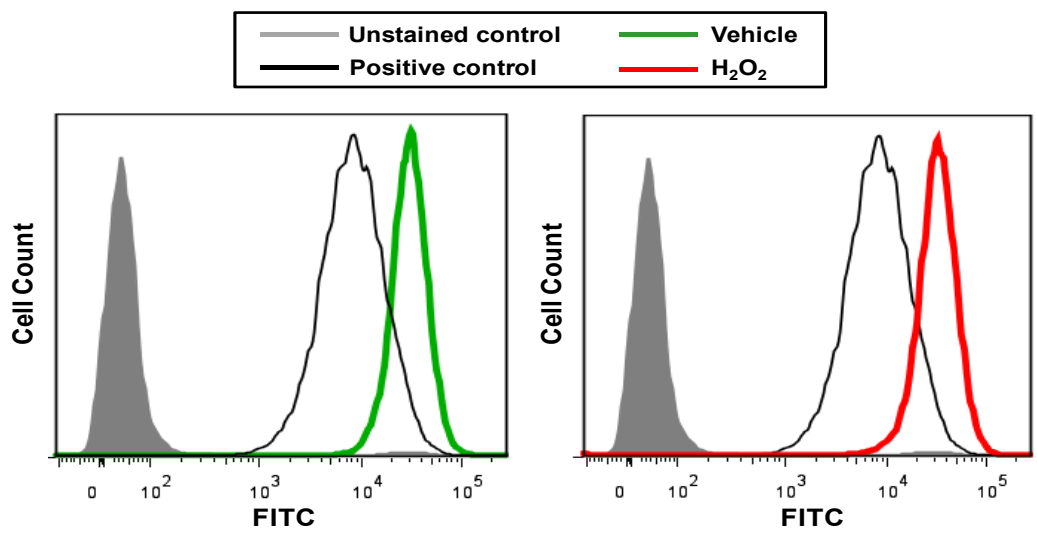

(A)

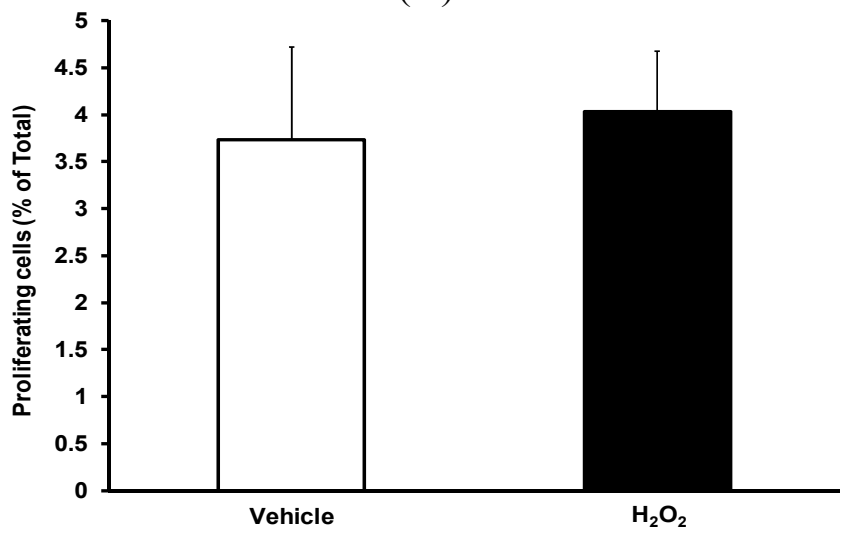

(B)

\subsection{Gene Silencing of ARPC2 Attenuates VSMC Migration}

To investigate whether ARPC2 plays a role in VSMC migration, we used siRNA to gene silence ARPC2, treated VSMC with vehicle or $\mathrm{H}_{2} \mathrm{O}_{2}$, and measured migration as described in Figure 4. ARPC2 protein expression was suppressed $69 \%$ by ARPC2 siRNA compared to Scrmb control (Figure 6A). $\mathrm{H}_{2} \mathrm{O}_{2}$ treatment significantly increased migration of Scrmb siRNA-treated VSMC compared to vehicle treatment (Figure 6B,C). Importantly, gene silencing of ARPC2 abolished the effect of $\mathrm{H}_{2} \mathrm{O}_{2}$ on VSMC migration. These data demonstrate that $\mathrm{H}_{2} \mathrm{O}_{2}$ stimulates VSMC migration via ARPC2, providing a new role for ARPC2 as a downstream modulator of Nox signaling and possibly the effector of Nox1-induced VSMC migration. 
Figure 6. $\mathrm{H}_{2} \mathrm{O}_{2}$ stimulates VSMC migration via ARPC2. ARPC2 and Scrmb siRNA-transfected VSMC were incubated with vehicle or $\mathrm{H}_{2} \mathrm{O}_{2}(50 \mu \mathrm{M})$ for $24 \mathrm{~h}$. Cell migration was determined by wounding of VSMC monolayers. Images were captured at 0 and $24 \mathrm{~h}$. (A) Representative Western blot showing ARPC2 and $\beta$-actin expression in Scrmb- and ARPC2-siRNA-treated VSMC. Images are representative of three independent experiments with similar results; (B) Representative images of wound healing at 0 and $24 \mathrm{~h}$ after scratch are shown (original magnification, $\times 5$ ). Dashed lines denote the approximate edge of the wound at 0 and $24 \mathrm{~h}$ time points; (C) Quantitative assessment of VSMC migration $(n=6)$. Data represent the mean \pm SEM. $* p<0.05 v s$. Scrmb siRNA + vehicle treatment; ${ }^{\#} p<0.05$ vs. Scrmb siRNA $+\mathrm{H}_{2} \mathrm{O}_{2}$ treatment.

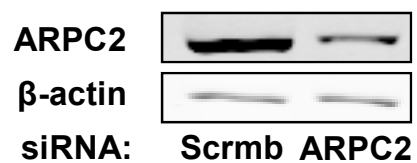

(A)

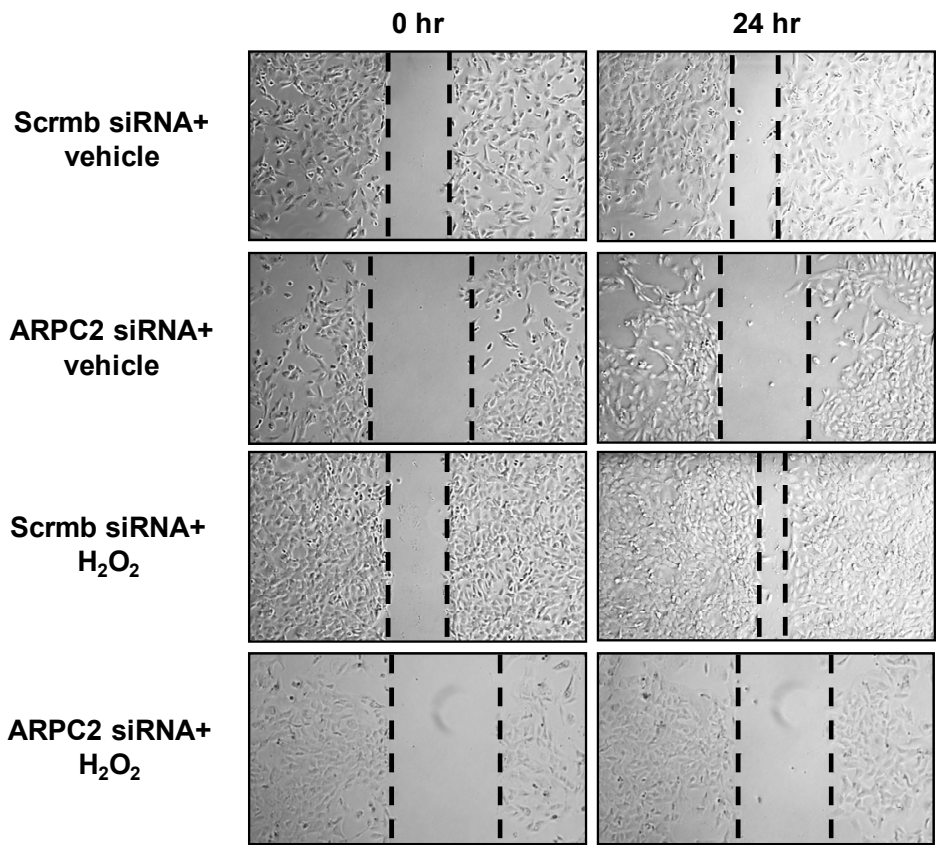

(B)

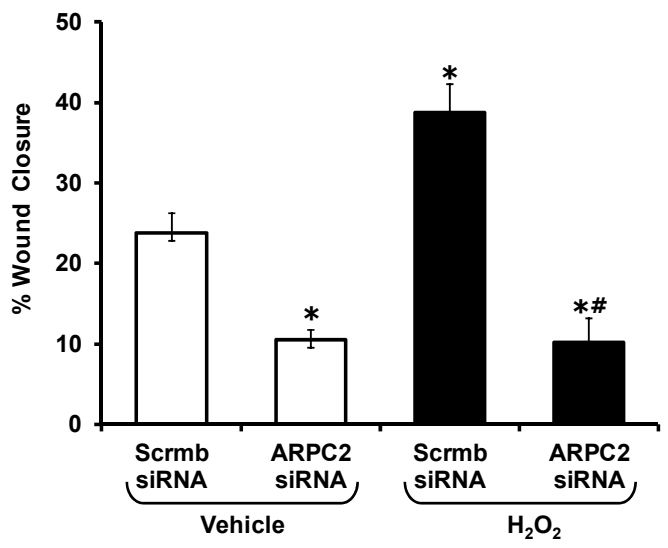

(C) 


\subsection{Pharmacological Inhibition of p38 MAPK Attenuates $\mathrm{H}_{2} \mathrm{O}_{2}$-Induced ARPC2 Expression}

Nox enzymes are known to activate p38 mitogen-activated protein kinase (p38 MAPK) [19-21] and an in vivo connection between $\mathrm{H}_{2} \mathrm{O}_{2}$ and $\mathrm{p} 38 \mathrm{MAPK}$ was recently demonstrated by our laboratory [18]. In addition, a recent study demonstrated that pharmacological inhibition of p38 MAPK inhibits VSMC migration in vitro [22]. Consequently, we investigated the involvement of p38 MAPK as a potential signaling mediator in oxidant-induced Nox1-dependent ARPC2 expression and VSMC migration. Indeed, while an association may be inferred as such [23,24], to date no connection has been demonstrated between p38 MAPK and ARPC2. To test this hypothesis, VSMC were transfected with Scrmb or Nox1 siRNA and treated with $\mathrm{H}_{2} \mathrm{O}_{2}(50 \mu \mathrm{M}, 3 \mathrm{~h})$, followed by Western blot for phospho- and total-p38 MAPK kinase. As shown in Supplemental Figure $\mathrm{S} 1, \mathrm{H}_{2} \mathrm{O}_{2}$ treatment significantly increased the level of phospho-p38 relative to total p38 (indicative of its activation) compared to vehicle treatment. Gene silencing of Nox1 abolished p38 MAPK phosphorylation in $\mathrm{H}_{2} \mathrm{O}_{2}$-treated VSMC. These data indicate that $\mathrm{H}_{2} \mathrm{O}_{2}$ leads to activation of p38 MAPK in a Nox1-dependent mechanism. To investigate whether p38 MAPK is upstream of Nox1-induced ARPC2 expression, VSMC were incubated with the p38 MAPK inhibitor SB203580 (1 $\mu \mathrm{M}, 1 \mathrm{~h})$ before $\mathrm{H}_{2} \mathrm{O}_{2}$ treatment. As shown in Figure 7, inhibition of p38 MAPK attenuated $\mathrm{H}_{2} \mathrm{O}_{2}$-induced ARPC2 protein expression, consistent with a role for 338 MAPK activation in this process.

Figure 7. Inhibition of p38 MAPK pathway attenuates $\mathrm{H}_{2} \mathrm{O}_{2}$-induced ARPC2 expression. VSMC were pre-treated with the p38 MAPK inhibitor (p38i) SB203580 (1 $\mu \mathrm{M}, 1 \mathrm{~h}$, Millipore), followed by treatment with vehicle or $\mathrm{H}_{2} \mathrm{O}_{2}(50 \mu \mathrm{M})$ for $3 \mathrm{~h}$. VSMC lysates were subjected to Western blot and probed with polyclonal antibodies against ARPC2 and $\beta$-actin. (A) Representative Western blot showing ARPC2 and $\beta$-actin expression in control- and p38i-treated VSMC incubated with vehicle or $\mathrm{H}_{2} \mathrm{O}_{2}$; (B) Bar graphs representing averaged optical density data expressed as a ratio of ARPC2 to $\beta$-actin $(n=4)$. Data represent the mean \pm SEM. ${ }^{*} p<0.05 v s$. Control + vehicle treatment. ${ }^{\#} p<0.05 v s$. Control $+\mathrm{H}_{2} \mathrm{O}_{2}$ treatment.

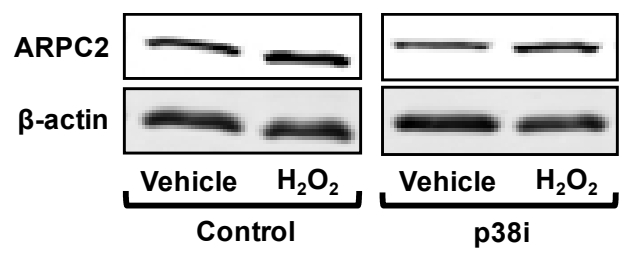

(A)

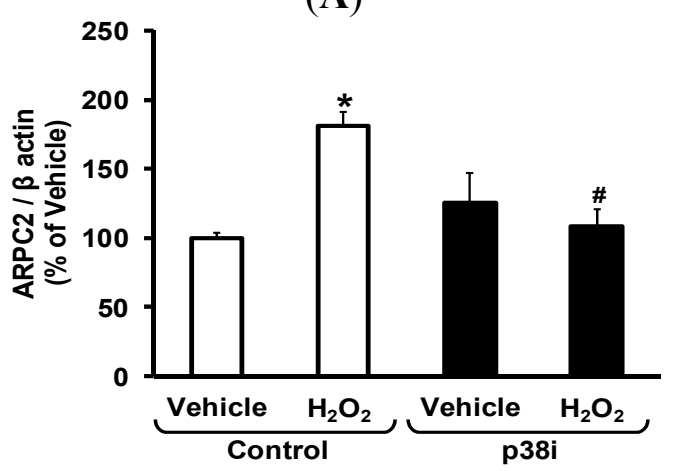

(B) 
Since p38 MAPK signaling is linked to NF- $\mathrm{B}$ activation $[25,26]$, we further investigated whether inhibition of the NF- $\kappa$ B pathway attenuates ARPC2 expression in response to $\mathrm{H}_{2} \mathrm{O}_{2}$. One strategy used to block the NF- $\kappa$ B pathway is the pharmacological inhibition of I $\kappa B$ kinase (IKK). IKK is responsible for phosphorylating the inhibitory I $\kappa$ B protein, thereby releasing it from NF- $\kappa B$, allowing for NF- $\kappa B$ activation [27]. VSMC were pre-treated with the IKK inhibitor wedelolactone $(60 \mu \mathrm{M} 1 \mathrm{~h}$, Millipore) [27,28], incubated with $\mathrm{H}_{2} \mathrm{O}_{2}$, and investigated for ARPC2 expression. Interestingly, our findings demonstrated that pharmacological inhibition of IKK does not inhibit $\mathrm{H}_{2} \mathrm{O}_{2}$-induced ARPC2 expression (data not shown). These data suggest that a transcription factor other than NF- $\mathrm{B}$ is responsible for oxidant-induced Nox1- and p38 MAPK-mediated ARPC2 expression. Our data are also consistent with the literature demonstrating that higher concentrations of $\mathrm{H}_{2} \mathrm{O}_{2}$ than were used in the present study may be required for NF- $\kappa$ B activation [29].

Further studies are required to identify this transcription factor in VSMC. It is also possible that post-translational and post-transcriptional modifications of ARPC2 regulated by the Nox1-p38 MAPK pathway may play a role. For example, attenuated ubiquitination or increased mRNA stability may lead to increased ARPC2 protein levels independent of de novo mRNA expression. Indeed, p38 MAPK has been shown to increase mRNA stability in vascular cells [30]. Taken together, the data presented herein suggest a signaling pathway whereby Nox1-derived ROS lead to increased ARPC2 protein expression via p38 MAPK kinase phosphorylation. The activation of this pathway leads to increased VSMC migration in vitro, suggesting a potentially important role of this signaling cascade in vascular hyperplasia and related pathologies in vivo.

\section{Experimental Section}

\subsection{Cell Culture}

Rat aortic vascular smooth muscle cells (VSMC; Lonza, Walkersville, MD, USA) were grown in Dulbecco's Modified Eagle's medium (Mediatech, Inc. Manassas, VA, USA) containing 10\% heat-inactivated fetal bovine serum (FBS), 100 units/mL penicillin, and $100 \mu \mathrm{g} / \mathrm{mL}$ streptomycin. Cells were used at passages 3-10 [31].

\subsection{Gene Silencing}

VSMC were grown to 30\%-50\% confluence and transfected with siRNA against Nox1 or ARPC2 (Stealth RNAi ${ }^{\mathrm{TM}}$, Invitrogen, Carlsbad, CA, USA) using the transfection reagent Lipofectamine 2000 (Invitrogen, Carlsbad, CA, USA) according to the manufacturer's protocol. To control for possible non-specific effects of siRNA, Stealth RNAi ${ }^{\text {TM }}$ siRNA negative controls were applied. $48 \mathrm{~h}$ after transfection VSMC were serum starved $(0.1 \% \mathrm{FBS} ; 24 \mathrm{~h})$, treated with vehicle or $\mathrm{H}_{2} \mathrm{O}_{2}(50 \mu \mathrm{M}, 3 \mathrm{~h})$, and assayed. Knockdown of Nox1 was confirmed previously [10]. ARPC2 knockdown was confirmed by Western blot.

\subsection{Western Blot}

Western blot was used to assess ARPC2 expression and p38 MAPK phosphorylation and expression in response to experimental manipulation. Seventy two hours after transfection, VSMC 
lysates were subjected to SDS-PAGE/Western blot with a polyclonal antibody against ARPC2 (Aviva Systems Biology, San Diego, CA, USA), total p38 MAPK (Cell Signaling) and $\beta$-actin (Santa Cruz Biotechnology, Dallas, TX, USA) and monoclonal antibody against phospho-p38 MAPK (Cell Signaling). Membranes were then incubated with the appropriate secondary antibodies (Li-Cor Biotechnology, Lincoln, NE, USA). Blots were scanned using the Odyssey Infrared Imaging System (Li-Cor Biotechnology) and blot density was quantified using ImageJ software (http://rsbweb.nih.gov/ij/).

\subsection{Proteomic Analysis Using Two-Dimensional Differential In-Gel Electrophoresis (2D-DIGE) Combined with Mass Spectroscopy (MS)}

\subsubsection{D-DIGE}

2D-DIGE and protein identification by mass spectroscopy were performed by Applied Biomics, Inc. (Hayward, CA, USA). Cultured VSMC were transfected with Scrmb or Nox1 siRNA (Invitrogen), treated with vehicle or $50 \mu \mathrm{M} \mathrm{H}_{2} \mathrm{O}_{2}$ for $3 \mathrm{~h}$, and $5 \mathrm{mg}$ of pelleted cells were lysed in $100 \mu \mathrm{L}$ of $2 \mathrm{D}$ cell lysis buffer (30 mM Tris-HCl, pH 8.8, containing $7 \mathrm{M}$ urea, $2 \mathrm{M}$ thiourea, and 4\% CHAPS). Protein concentration was measured using the Bio-Rad method (Hercules, CA, USA). $30 \mu \mathrm{g}$ of protein were mixed with $1.0 \mu \mathrm{L}$ of diluted CyDye (GE Healthcare, Uppsala, Sweden) and kept in the dark on ice for $30 \mathrm{~min}$. The labeling reaction was stopped by adding $1.0 \mu \mathrm{L}$ of $10 \mathrm{mM}$ lysine to each sample and incubating in the dark on ice for an additional $15 \mathrm{~min}$. The labeled samples were then mixed together. $2 \times 2 \mathrm{D}$ gel sample buffer ( $8 \mathrm{M}$ urea, $4 \%$ CHAPS, $20 \mathrm{mg} / \mathrm{mL}$ DTT, $2 \%$ pharmalytes, and trace amount of bromophenol blue), and $100 \mu \mathrm{L}$ destreak solution and rehydration buffer ( $7 \mathrm{M}$ urea, $2 \mathrm{M}$ thiourea, 4\% CHAPS, $20 \mathrm{mg} / \mathrm{mL}$ DTT, 1\% pharmalytes, and a trace amount of bromophenol blue) were added to the labeling mix to bring the total volume to $250 \mu \mathrm{L}$. The samples were mixed and centrifuged before loading into the IPG strip holder for sample loading. After loading the labeled samples, isoelectric focusing (IEF; pH 3-10 Linear) was run following the protocol provided by GE Healthcare. The immobilized $\mathrm{pH}$ gradient (IPG) strips were incubated in freshly made equilibration buffer-1 (50 mM Tris-HCl, pH 8.8, containing $6 \mathrm{M}$ urea, 30\% glycerol, 2\% SDS, a trace amount of bromophenol blue, and $10 \mathrm{mg} / \mathrm{mL}$ DTT) for $15 \mathrm{~min}$ with gentle shaking. The strips were rinsed in freshly made equilibration buffer- $(50 \mathrm{mM}$ Tris- $\mathrm{HCl}, \mathrm{pH} 8.8$, containing $6 \mathrm{M}$ urea, 30\% glycerol, $2 \%$ SDS, trace amount of bromophenol blue, and $45 \mathrm{mg} / \mathrm{mL}$ iodoacetamide) for $10 \mathrm{~min}$ with gentle shaking. Next the IPG strips were rinsed in the SDS-gel running buffer before transfer onto $12 \%$ SDS-gels. The SDS-gel was run at $15{ }^{\circ} \mathrm{C}$ until the dye front ran out of the gels. Gel images were scanned immediately following the SDS-PAGE using Typhoon TRIO (GE Healthcare). The scanned images were analyzed by Image Quant software (version 6.0, GE Healthcare), followed by in-gel analysis using DeCyder software version 6.5 (GE Healthcare). The fold change of protein expression levels was obtained from in-gel DeCyder analysis.

\subsubsection{Mass Spectrometry}

The spots of interest were "cherry-picked" by Ettan Spot Picker (GE Healthcare) based on the in-gel analysis and spot selection design by DeCyder software. Gel spots were washed a few times 
then digested in-gel with modified porcine trypsin protease (Promega, Madison, WI, USA). The digested tryptic peptides were desalted using a Zip-tip C18 (Millipore, Billerica, MA, USA). Peptides were eluted from the Zip-tip with $0.5 \mu \mathrm{L}$ of matrix solution ( $\alpha$-cyano-4-hydroxycinnamic acid $5 \mathrm{mg} / \mathrm{mL}$ in $50 \%$ acetonitrile, $0.1 \%$ trifluoroacetic acid, $25 \mathrm{mM}$ ammonium bicarbonate) and spotted on a MALDI plate. MALDI-TOF MS and TOF/TOF tandem MS/MS were performed on AB SCIEX TOF/TOFTM 5800 System (AB SCIEX, Framingham, MA, USA). MALDI-TOF mass spectra were acquired in reflectron positive ion mode, averaging 4000 laser shots per spectrum. TOF/TOF tandem MS fragmentation spectra were acquired for each sample, averaging 4000 laser shots per fragmentation spectrum on each of the 7-10 most abundant ions present in each sample (excluding trypsin autolytic peptides and other known background ions). Both of the resulting peptide mass and the associated fragmentation spectra were submitted to GPS Explorer workstation equipped with MASCOT search engine (Matrix Science, Boston, MA, USA) to search the database of National Center for Biotechnology Information, non-redundant (NCBI-nr). Searches were performed using the following criteria in the search parameters: (1) no constraint of protein molecular weight or isoelectric point; (2) allowing for variable carbamidomethylation of cysteine and oxidation of methionine residues, and (3) allowing for one missed cleavage. Candidates with either protein score C.I.\% or Ion C.I.\% greater than 95 were considered significant.

\subsection{Wound Migration "Scratch” Assay}

VSMC monolayers were serum starved $(0.1 \%$ FBS; $24 \mathrm{~h})$ and scratched/wounded using a sterile $200 \mu \mathrm{L}$ pipette tip (BD Biosciences, San Diego, CA, USA). Each experiment was run in triplicates. For each replicate 6 images were captured for assessing wound area. Photos were taken immediately after wounding $(0 \mathrm{~h})$ and at $24 \mathrm{~h}$ post-wounding using a Zeiss Axiovert $40 \mathrm{CFL}$ microscope. To quantify migration, wound area was calculated using ImageJ software (http://rsbweb.nih.gov/ij/) at 0 and $24 \mathrm{~h}$ time points, and expressed as \% wound closure for each treatment.

\subsection{Carboxyfluorescein Succinimidyl Ester (CFSE) Quantification}

VSMC proliferation was assessed using the CellTrace ${ }^{\mathrm{TM}}$ CFSE Cell Proliferation Kit according to the manufacturer's instructions (Invitrogen). VSMC were seeded into 6-well tissue culture dishes, serum starved $(0.1 \% \mathrm{FBS})$ for $24 \mathrm{~h}$, and incubated with $1.25 \mu \mathrm{M}$ CFSE for $15 \mathrm{~min}$ in phosphate-buffered saline (PBS). Cells were washed with PBS and incubated with vehicle or $\mathrm{H}_{2} \mathrm{O}_{2}$ $(50 \mu \mathrm{M})$ for $24 \mathrm{~h}$. VSMC incubated for $48 \mathrm{~h}$ in the presence of complete growth media (10\% FBS) were used as positive controls. CFSE fluorescence was evaluated using a BD LSRFortessa ${ }^{\mathrm{TM}}$ cell analyzer and flow data were analyzed using FlowJo (version 10).

\subsection{Statistical Analysis}

All results are expressed as mean \pm SEM. Significance of the differences were assessed by Student's $t$-test, one- or two-way ANOVA followed by a Bonferroni post-hoc test as appropriate for the particular experiment and treatment groups. A value of $p<0.05$ was considered to be statistically significant. 


\section{Conclusions}

In this manuscript, we identify ARPC2 as a new downstream target of Nox1 activation and demonstrate the importance of Nox1/ARPC2 signaling axis in VSMC migration. The data presented herein also support a role for p38 MAPK as an upstream mediator of Nox1-induced ARPC2 expression and VSMC migration. This previously unreported signaling pathway sheds important light on the pathological role of Nox/ROS in VSMC and is expected to open a new area of investigation into the role of ARPC2 in vascular disease. The current work also introduces a potential therapeutic target downstream of Nox1 that may offer alternative strategies for disruption of pro-migratory pathways under conditions of oxidative stress.

\section{Acknowledgments}

This work was supported by National Institutes of Health grants R01HL079207 (to P.J. Pagano), P01HL103455-01 (to P.J. Pagano), 1K99HL114648-01A1 (to G. Csanyi), and also by American Heart Association (AHA) grant 10POST3030009 (to G. Csanyi). The study was supported by the Institute for Transfusion Medicine and the Hemophilia Center of Western Pennsylvania. The authors wish to thank Iulia Dana Popescu for her assistance with the flow cytometry experiments. The authors wish to thank Daniel Meijles and Laura Pliske for their assistance with the editing of this manuscript.

\section{Conflicts of Interest}

The authors declare that they have no conflict of interests.

\section{References}

1. Madhur, M.S.; Funt, S.A.; Li, L.; Vinh, A.; Chen, W.; Lob, H.E.; Iwakura, Y.; Blinder, Y.; Rahman, A.; Quyyumi, A.A.; et al. Role of interleukin 17 in inflammation, atherosclerosis, and vascular function in apolipoprotein e-deficient mice. Arterioscler. Thromb. Vasc. Biol. 2011, 31, $1565-1572$.

2. Sparks, M.A.; Makhanova, N.A.; Griffiths, R.C.; Snouwaert, J.N.; Koller, B.H.; Coffman, T.M. Thromboxane receptors in smooth muscle promote hypertension, vascular remodeling, and sudden death. Hypertension 2013, 61, 166-173.

3. Johnson, J.L.; Dwivedi, A.; Somerville, M.; George, S.J.; Newby, A.C. Matrix metalloproteinase (MMP)-3 activates MMP-9 mediated vascular smooth muscle cell migration and neointima formation in mice. Arterioscler. Thromb. Vasc. Biol. 2011, 31, e35-e44.

4. Al Ghouleh, I.; Khoo, N.K.; Knaus, U.G.; Griendling, K.K.; Touyz, R.M.; Thannickal, V.J.; Barchowsky, A.; Nauseef, W.M.; Kelley, E.E.; Bauer, P.M.; et al. Oxidases and peroxidases in cardiovascular and lung disease: New concepts in reactive oxygen species signaling. Free Radic. Biol. Med. 2011, 51, 1271-1288.

5. Csanyi, G.; Taylor, W.R.; Pagano, P.J. NOX and inflammation in the vascular adventitia. Free Radic. Biol. Med. 2009, 47, 1254-1266. 
6. Szocs, K.; Lassegue, B.; Sorescu, D.; Hilenski, L.L.; Valppu, L.; Couse, T.L.; Wilcox, J.N.; Quinn, M.T.; Lambeth, J.D.; Griendling, K.K. Upregulation of Nox-based NAD(P)H oxidases in restenosis after carotid injury. Arterioscler. Thromb. Vasc. Biol. 2002, 22, 21-27.

7. Griendling, K.K. Novel $\mathrm{NAD}(\mathrm{P}) \mathrm{H}$ oxidases in the cardiovascular system. Heart 2004, 90, 491-493.

8. Csanyi, G.; Cifuentes-Pagano, E.; Al Ghouleh, I.; Ranayhossaini, D.J.; Egana, L.; Lopes, L.R.; Jackson, H.M.; Kelley, E.E.; Pagano, P.J. Nox2 B-loop peptide, Nox2ds, specifically inhibits the NADPH oxidase Nox2. Free Radic. Biol. Med. 2011, 51, 1116-1125.

9. Dikalov, S.I.; Dikalova, A.E.; Bikineyeva, A.T.; Schmidt, H.H.; Harrison, D.G.; Griendling, K.K. Distinct roles of Nox1 and Nox4 in basal and angiotensin II-stimulated superoxide and hydrogen peroxide production. Free Radic. Biol. Med. 2008, 45, 1340-1351.

10. Al Ghouleh, I.; Frazziano, G.; Rodriguez, A.I.; Csanyi, G.; Maniar, S.; St Croix, C.M.; Kelley, E.E.; Egana, L.A.; Song, G.J.; Bisello, A.; et al. Aquaporin 1, Nox1, and Ask1 mediate oxidant-induced smooth muscle cell hypertrophy. Cardiovasc. Res. 2013, 97, 134-142.

11. Brown, D.I.; Griendling, K.K. Nox proteins in signal transduction. Free Radic. Biol. Med. 2009, 47, 1239-1253.

12. Sung, H.J.; Eskin, S.G.; Sakurai, Y.; Yee, A.; Kataoka, N.; McIntire, L.V. Oxidative stress produced with cell migration increases synthetic phenotype of vascular smooth muscle cells. Ann. Biomed. Eng. 2005, 33, 1546-1554.

13. Goley, E.D.; Rammohan, A.; Znameroski, E.A.; Firat-Karalar, E.N.; Sept, D.; Welch, M.D. An actin-filament-binding interface on the Arp2/3 complex is critical for nucleation and branch stability. Proc. Natl. Acad. Sci. USA 2010, 107, 8159-8164.

14. Goley, E.D.; Welch, M.D. The ARP2/3 complex: An actin nucleator comes of age. Nat. Rev. Mol. Cell Biol. 2006, 7, 713-726.

15. Liao, G.; Simone, B.; Liu, G. Mis-localization of Arp2 mRNA impairs persistence of directional cell migration. Exp. Cell Res. 2011, 317, 812-822.

16. Rauhala, H.E.; Teppo, S.; Niemela, S.; Kallioniemi, A. Silencing of the ARP2/3 complex disturbs pancreatic cancer cell migration. Anticancer Res. 2013, 33, 45-52.

17. Suraneni, P.; Rubinstein, B.; Unruh, J.R.; Durnin, M.; Hanein, D.; Li, R. The Arp2/3 complex is required for lamellipodia extension and directional fibroblast cell migration. J. Cell Biol. 2012, 197, 239-251.

18. Cascino, T.; Csanyi, G.; Al Ghouleh, I.; Montezano, A.C.; Touyz, R.M.; Haurani, M.J.; Pagano, P.J. Adventitia-derived hydrogen peroxide impairs relaxation of the rat carotid artery via smooth muscle cell p38 mitogen-activated protein kinase. Antioxid. Redox. Signal 2011, 15, $1507-1515$.

19. Di Lisa, F.; Kaludercic, N.; Paolocci, N. Beta(2)-Adrenoceptors, NADPH oxidase, ROS and p38 MAPK: Another 'radical' road to heart failure? Br. J. Pharmacol. 2011, 162, 1009-1011.

20. Ushio-Fukai, M.; Alexander, R.W.; Akers, M.; Griendling, K.K. p38 Mitogen-activated protein kinase is a critical component of the redox-sensitive signaling pathways activated by angiotensin II. Role in vascular smooth muscle cell hypertrophy. J. Biol. Chem. 1998, 273, 15022-15029. 
21. Viedt, C.; Soto, U.; Krieger-Brauer, H.I.; Fei, J.; Elsing, C.; Kubler, W.; Kreuzer, J. Differential activation of mitogen-activated protein kinases in smooth muscle cells by angiotensin II: Involvement of p22phox and reactive oxygen species. Arterioscler. Thromb. Vasc. Biol. 2000, 20, 940-948.

22. Lo, H.M.; Tsai, Y.J.; Du, W.Y.; Tsou, C.J.; Wu, W.B. A naturally occurring carotenoid, lutein, reduces $\mathrm{PDGF}$ and $\mathrm{H}_{2} \mathrm{O}_{2}$ signaling and compromised migration in cultured vascular smooth muscle cells. J. Biomed. Sci. 2012, 19, 18.

23. Schindeler, A.; Lavulo, L.; Harvey, R.P. Muscle costameric protein, Chisel/Smpx, associates with focal adhesion complexes and modulates cell spreading in vitro via a Rac1/p38 pathway. Exp. Cell Res. 2005, 307, 367-380.

24. Singh, S.; Powell, D.W.; Rane, M.J.; Millard, T.H.; Trent, J.O.; Pierce, W.M.; Klein, J.B.; Machesky, L.M.; McLeish, K.R. Identification of the p16-Arc subunit of the Arp 2/3 complex as a substrate of MAPK-activated protein kinase 2 by proteomic analysis. J. Biol. Chem. 2003, 278, 36410-36417.

25. Huang, X.; Zhang, J.; Liu, J.; Sun, L.; Zhao, H.; Lu, Y.; Wang, J.; Li, J. C-reactive protein promotes adhesion of monocytes to endothelial cells via NADPH oxidase-mediated oxidative stress. J. Cell Biochem. 2012, 113, 857-867.

26. Piao, Y.J.; Seo, Y.H.; Hong, F.; Kim, J.H.; Kim, Y.J.; Kang, M.H.; Kim, B.S.; Jo, S.A.; Jo, I.; Jue, D.M.; et al. Nox 2 stimulates muscle differentiation via NF-kappaB/iNOS pathway. Free Radic. Biol. Med. 2005, 38, 989-1001.

27. Lim, W.S.; Ng, D.L.; Kor, S.B.; Wong, H.K.; Tengku-Muhammad, T.S.; Choo, Q.C.; Chew, C.H. Tumour necrosis factor alpha down-regulates the expression of peroxisome proliferator activated receptor alpha (PPARalpha) in human hepatocarcinoma HepG2 cells by activation of NF-kappaB pathway. Cytokine 2013, 61, 266-274.

28. Maalouf, S.W.; Talhouk, R.S.; Schanbacher, F.L. Inflammatory responses in epithelia: Endotoxin-induced IL-6 secretion and iNOS/NO production are differentially regulated in mouse mammary epithelial cells. J. Inflamm. 2010, 7, 58.

29. Oliveira-Marques, V.; Marinho, H.S.; Cyrne, L.; Antunes, F. Role of hydrogen peroxide in NF-kappaB activation: From inducer to modulator. Antioxid. Redox. Signal 2009, 11, 2223-2243.

30. Al Ghouleh, I.; Magder, S. NADPH oxidase-derived superoxide destabilizes lipopolysaccharide-induced interleukin 8 mRNA via p38, extracellular signal-regulated kinase mitogen-activated protein kinase, and the destabilizing factor tristetraprolin. Shock 2012, 37, 433-440.

31. Shimizu, H.; Hirose, Y.; Nishijima, F.; Tsubakihara, Y.; Miyazaki, H. ROS and PDGF-beta [corrected] receptors are critically involved in indoxyl sulfate actions that promote vascular smooth muscle cell proliferation and migration. Am. J. Physiol. Cell Physiol. 2009, 297, C389-C396.

(C) 2013 by the authors; licensee MDPI, Basel, Switzerland. This article is an open access article distributed under the terms and conditions of the Creative Commons Attribution license (http://creativecommons.org/licenses/by/3.0/). 